Binghamton University

The Open Repository @ Binghamton (The ORB)

The Society for Ancient Greek Philosophy Newsletter

$12-1969$

\title{
On the Antecedents of Aristotle's Bipartite Psychology
}

William W. Fortenbaugh

Rutgers University - New Brunswick/Piscataway, fortenb@scarletmail.rutgers.edu

Follow this and additional works at: https://orb.binghamton.edu/sagp

Part of the Ancient History, Greek and Roman through Late Antiquity Commons, Ancient Philosophy Commons, and the History of Philosophy Commons

\section{Recommended Citation}

Fortenbaugh, William W., "On the Antecedents of Aristotle's Bipartite Psychology" (1969). The Society for Ancient Greek Philosophy Newsletter. 187.

https://orb.binghamton.edu/sagp/187

This Article is brought to you for free and open access by The Open Repository @ Binghamton (The ORB). It has been accepted for inclusion in The Society for Ancient Greek Philosophy Newsletter by an authorized administrator of The Open Repository @ Binghamton (The ORB). For more information, please contact ORB@binghamton.edu. 
This paper will be concemed with the antecedents of Aristotle's biparite or moral psychology. It will consider two common theses: 1) Aristotle's bipartite psychology is in origin a popular psychology already present (if not oiearly formulated) in Euripides Nedea; 2) Aristotle's bipartite psychology developsd out of tripartition by collapsing together the two lower elements of tripartition. Roughly, I shall be affirming the first and rejecting the second thesis. In both cases I hope to develop and make more precise the origins of Aristotle's bipartite psychology.

The famous monologue of Medea (1021-1080) reveals an inner conflict between spirit and reason. 1.The monologue presents a kind of psychic dichotomy, and may be said to anticipate Aristotle's bipartite psychology in that it distinguishes spirit or enotion from both deliberation about means and also reasoned rellection about emotional response. In other words, the monologue pulls together in one passage two oppositions that have been depicted earlier in the play and that are essential for an understanding of bipartition. Let me develop this point by considering relevant parts of the Nedea.

At the beginning of the play we learn from the nurse that Medea is filled with hate and grief $(16,24-35)$, because she thinks herself dishonored by Jason $(20,26)$. Nedea's emotional state is not in doubt. What is in doubt and what especially troubles the nurse is Medea's plans or deliberations (bouleuein 37). Here we have a partial expression of the dichotomy of bipartition. Medea's anger and grief or more generally her emotions are contrasted with the deliberations that follow upon and are given direction by her emotions. Considering herself outraged and so desiring revenge, Medea must deliberate about how to achieve revenge. Some way or means must be discovered (260) before her emotion and desire for revenge can be translated effectively into action.

The same distinction between emotional response and means-end deliberation occurs later when Creon confronts Nedea and orders her to leave Corinth. Creon acknowledges being frightened of Medea, and explains his fear by pointing out that Madea is clever (sophe 285) and pained at the loss of Jason's love. In other words Medea is not only angered by Jason's behavior but is capable of following up her anger with successful deliberations about means to achieve revenge. This same distinction between emotion and cleverness occurs again when Creon says that he fears lest Medea be planning something (317) and then adds that a sharptempered (oxythymos 319) person is easier to guard against than a silent but clever (sophos 320) person. A sharped-tempered person responds emotionally straightway and without deliberation. The silent and clever person does not act without delibemation. In his case anger is the occasion for deliberation about means.

Emotion is distinct from means-end deliberation and this distinction is part of the dichotong of bipartition. Emotion is also distinguished from reasoned reflection about emotional response and this distinction, too, is part of the dichotomy of bipartition. We can gain a clearer understanding of this latte: distinction if we consider Medea's first meeting with Jason. During this meeting Modea criticizes herself for having followed and aided Jason, describing herself as eager (prothumos 485) rather than wise (sophotera 485). Medea does not, of course, mean that her actions on behalf of Jason were lacking in cleverness. On the conirary she makes clear that without her skills Jasom would never have escaped danger. (Note how she begins and ends her opening statement with the claim to have sared Jason $(476,515)$.) 
Fer point is simply that reason was not controlling emotion when she aided Jason. Her actions were motivated by the particular emotion of love. (At the opering: of the play the chorus made clear that in regard to her emotional side (thumgn 8) love (epoti 8) was dominate.) With this piece of self-analysis Jason is in full agreement. He credits Medoa with a subtle mind (529) but restricts her clever deliberations to means-end reasoning. Iove was dominate and determined the course of her deliberations (527-531). Medea's cleverness at finding the means to offect a desired goal is never in doubt. All Greece knows that Medea is clever (sophen 539). But if she is skilled in means-ond deliberations following upon emotional response, she is not similarly effective in reflecting upon and altering her emotional response in accordance with reasoned consideration (cf.600). In contrast Jason's actions -- or so Jason claims -- are guided by reasoned reflection. He is not motivated by desire (556). He has considered (bebouleumain 567) his actions and their consequences and so can claim to be wise (sophos 548).2.

A similar distinction between emotion and reasoned reflection appears during the seond meeting of Medea and Jason (866-893). In the course of this meeting, the emotion of Medea is alleged to be under the control of reasoned reflection. Medea begins by asking Jason to pardon her anger (orgas 870) and by saying that she has engaged in discussion (Iogon 872) with herse if. Then she subjests her angry emotion to criticism (873-879) and indicates that she will give up her anger (thymou 879). Claiming to have considered (ennoesas'882) her children and the impending exile without friiends, Medea states that she has exhibited a lack of good sense (aboulian 882,aphron 885) and that her anger has been foolish (883). She admits that her previous conduct was unreasonable but claims now to have considered (bebouleumai 893) the matter and come to a better understanding. Jason is fooled by Medea's speech and replies sympathetically. He allows that Medea's anger (orgas 909) was after all equite natural and that now at last Medea has come to better reasoning (boulen 913). He credits Medea with having reflected reasonably and having altered her emotions in accordance with reason.

Emotion, then, may be distinguished from reasoned reflection as well as from means-end deliberation. It is now time to look at Medea's monologue which, as I have suggested, pulls together both distinctions and so captures fully the dichotomy of bipartition. Medea begins the monologue by reflecting upon the evil consequences of her actions, by considering the personal loss involved in killing her children (1021-1039). This reflection together with the pathetic sight of her children 3. causes her to alter briefly her intentions. She abandons her plans (bouleumata) and states that she will take her children away with her (1040-1048). But her desire for full revenge returns swiftly. She chides herself for having listened to soft arguments (malthakous logous) and sends the children indoors to await death (1049-1055). Then for a second time she falters, addressing her spirit (thymas) and pointing out the joy that the children can bring in exile (1056-1058) This time her hesitation is of even shorter duration. Once again she determines to kill the children. She is quite conscious of the terrible path she has chosen for herself and even more terrible path that she has chosen for the children (1067-1068). But now she does not falter. She understands (manthano) that her forthcoming deed is evil (1078) but she also realizes that her reasoned reflections are unable to alter her angry desire for full revenge. As she puts it, thymos is stronger than bouleumata (1079).

In this monologue Medea's emotions are distinguised quite clearly: from her bouleumata. And these bouleumata include both the deliberate plans $(1044,1048)$ which follow upon and are given direction by emotion and also the reflections (1079) which consider the reasonableness of emotion and on occasion alter emotion. Using bouleumata in an inclusive sense, Euripides has captured the dichotomy of bipartition: deliberation and reflection in contrast with emotional response. 4. 
4. It is this dichotomy with which Aristotle works and which enables him at one time to treat reason as something that follows emotion and at another time to treat reason as something that controls emotion. When Aristotle says that the alogical soul is obedient to reason (EN 1098al, 1002b3I), he is thinking primarily of reasoned reflection and its ability to control and alter emotion. A virtuous man subjects his emotional responses to reasoned reflection. $2 \cdot$ He contrasts with Nedea in that he heeds reason, altering or abandoning his emotional responses according to the dictates of reasoned reflection. 6. Still, the virtuous man is like Medea in regard to means-end deliberation. In this respect his reason may be said to follow his emotion. When Aristotle says that moral virtue makes correct the goal and practical wisdom the means (EN 1144a7-9, 1145a5-6), he is thinking primarily of means-end deliberation in relation to emotional response. Neans-end deliberation follows upon and is given direction by emotional response. 7. - Since the latter is the province of moral virtue, and the former of practical wisdom, Aristotle can say that moral virtue makes correct the goal and practical wisdom the means without implying that practical wisdom is altogether restricted to means-end deliberations. 8. The distinction between moral virtue and practical wisdom is founded upon the dichotomy of bipartition and this dichotomy is in a way complex. Reason is related to emotion not only as deliberation that follows emotion but also as reflection that can control emotion. I'his twofold relationship between reason and emotion is fundamental to Aristotle's moral psychology. Yet it is not an Aristotelian discovery. It was ready at hand in popular. thought and more or less clearly expressed in a tragedy like the Medea. Aristotle along with other members of the Academy gave the dichotomy formal recognition, but they did not invent it.9.

II

If Aristotle's bipartite psychology developed out of a popular distinction between reason and emotion as explained in the preceding section, can it also be said to have developed out of Plato's tripartite psychology? More precisely, did Aristotle's own moral psychology develop through bringing together the thymoeides and epithymetikon of tripartition? Here I think we must say that not on Iy is Aristotle is bipartite psychology significantly different from such a bipartite version of tripartition 10.but also that Aristotle himself was aware of the difference and prepared to criticize bipartition whenever it took the form of a simplified tripartition. Perhaps I can support this claim and at the same teimer up a persistent misunderstand in the De Anima.

Here (432a22-b7) at the beginning of his account of locomotion, Aristotle makes some prefadtory remarks about psychic divisions and criticizes cursorily both those persons who offer a tripartite psychology and those persons who offer a bipartite psychology $(432 a 24-26)$. It has been widely assumed and sometimes stated that this criticism of persons advancing bipartition is in part at least a self-criticism. Aristotle's remarks, we are told, are directed not only against members of the Academy who may have developed or advanced a bipartite psychology, but also against Aristotle himself insofar as he employed bipartition both in earlier writings like the Protrepticus and De Justitia and in more mature treatises like the Ethics and Politics. 11. This view seems to me unacceptable. I want to suggest that Aristotle's criticism of bipartition is not a self-criticism. His remarks are directed against members of the Academy who had simply altered tripartion by collapsing the spirited and appetitive elements into a single psychic part and thereby created a particular kind of bipartite psychology. Aristotle's own bipartite or moral psychology differs in important ways from this Academic version and so should not be confused with it. 
2 At this point he adds a note to the effect that the rational element

4.0

We may begin by considering two passages that create difficulties for anyone who tries to identify the bipartition criticized in the De Anima with Aristotle's own moral psychology. One of these passages occurs in Book I of the Nicomachean Ethics (1097b33-109825). Here Aristotle is trying to pin down the function of man. Toward this end he introduces first the nutritive life of plants, then the sensitive life of animals, and finally the practical life of the rational element is twofold: one part being obedient to reason and the other part possessing it and being deliberative (1098a/4-5). 12. This note is important for it clearly relates Aristotle's bipartite or moral psychology to his scientific psychology. The division between the alogical and logical halves of moral psychology occurs within the scilentific faculty of intellect. The division does not coincide with the scientific division between sensation and intellect. The reason for this is clear enough. 13. Bipartition is a human psychology that is useful for explaining intelligent (human) actions. 14. It is based upon a distinction between emotional response (which is intelligent in that it necessarily involves certain kinds of cognitions: 15) and reasoned deliberation. The alogical soul is primarily the capacity for emotional response, while the logical soul is primarily the capacity for reasoned deliberation. Both acts are intelligent, so that both capacities are cognitive. In contrast the scientific faculty of sensation is not cognitive and so can be possessed by animals that cannot act intelligently.

It is, of course, possible to extend the alogical soul to include noncognitive functions like nutrition and sensation. Aristotle does this in respect to nutrition at EN 1102a32-bI2 (cf. EE 1219b31-32). But neither nutrition nor sensation are essential components of the alogical soul. 16.Bipartition is fundamentally a distinction between two kinds of intelligent action. Moreover, there can be no serious question about including either nutrition or sensation in the logical soul of Aristotle's moral psychology. Aristotle cannot seriously suggest that someone might try to house the scientific faculty of sensation within the logical soul of his own moral psychology. Such an attempt would be foolish. In regard to Aristotle's own bipartite psychology the assignation of sensation is cleax. It is properly located outside (or "below") the dichotomy, though" the alogical soul.: can be extended ("downward") to include it. And if this is true, difficulties arise for anyone who will refer the criticisms of bipartition advanced in the De Anima to Aristotle's own moral psychology. For in terms of Aristotle's own bipartite psychology, there can be no question concerning the assignation of the aisthetikon. If the De Anima passage (432a30-3I) presents a serious puzzle, it must be directed against a different version of bipartition that suggests the possibility of locating sensation in the logical as well as in the alogical part. As we shall see, the Timaeus suggest such a version of bipartition.

The second passage that causes difficulties occurs in the Politics (1334b6-28). Here Aristotle is concerned to point out that habituation is employed in education before logos is employed. In the course of his argument Aristotle introduces his own moral psychology and locates thymos, boulesis, and epithymia on the alogical side of the dichotomy (1334b22-23). This creates dilfficulties, if it is assumed that Aristotle's criticism of bipartition in the De Anima is directed in part against his own moral psychology. For in the De Anima Aristotle locates boulesis on the logical side $(432 \mathrm{~b} 5)$. This location may be necessary, if Aristotle is going to charge bipartition with splitting up orexis. But the location needs considerable explanation. if it is assumed that the bipartition in question is Aristotle's own moral pyschology. For as the Politics makes clear, Aristotle's own bipartite psychology locates boulesis on the alogical side. 17.

These difficulties can be removed if we understand that bipartition takes more than one form. The fact that in the De Anima Aristotle does not seem to include himself among the proponents of bipartition and then brings forth amgumerts 
Iargely ineffective against his own moral psychology becomes intelligible when we realize that Aristotle is not critizing his own bipartite psychology. Rather he is criticizing a particular kind of bipartition that was developed in the Academy out of tripartition by bringing together the spirited and the appetitive faculties. A closer look at $432 \mathrm{~b} 5-6$ will help to make this point clearer. Here Aristotle is criticizing bipartition, but instead of employing the label to logon echon to refer to the logical half, he uses the label logistikon which belongs to the vocabulary of tripartition (432a25). Is this a confusion? Perhaps, but only a very minor one. For Aristotle is criticizing a variety of bipartition which identifies the logical half with the logistikon of tripartition. Aristotle has in mind that kind of bipartition which is already suggested in the Republic 18 . and clearly indicated in the Timaeus - a dialogue which groups together the spirited and appetitive elements as the mortal soulanpposes this combination to the logistikon as the immortal soul. Apparently tripartition and this related form of bipartition enjoye a contemporaneous Iife within the Academy. At least the Topics, which seems frequently to reflect discussion in the Academy, introducas for illustrative purposes not only tripartition but also that version of bipartition which is a variation on tripartition (129a10-16). 19. We may suspect that just as in the Topics Aristotle takes note of two Academic psychologies, so in the De Anima Aristotle is concerned with members of the Academy, when he criticizes those who advance tripartition and those who advance bipartition (432a24-26).

The Timaeus can help us to understand Aristotle's charge that the aisthetikon cannot be comfortably located in either the logical or alogical soul (432a30-3I). While the Timaeus introduces tripartition and even assigns each of the three psychic parts its own bodily location, the Timasus, as we have already said, presents a bipartite version of tripartition. The logistikon is divine and elevated spatially to a seat in the head. The other two psychic parts are mortal and are located in the trunk of the body. For our purposes the important point is that the Timaeus not only employs this bipartite version of tripartition but also attempts to handle sense perception. And this attempt seems to result in just the kind of difficulty which Aristotle asserts does occur when the sensitive. faculty is referred to bipartition. For at one time the Timaeus seems to treat the logistikon or immortal soul as the center of consciousness to which sensory motions are transmitted (43-44, 64B), and at another time it seems to associate the mortal soul with aisthesis (6IC, 69D). In this regard certain passages are especially difficult, if not confusing. In explaining pleasure and pain, the Timaeus first connects sensation with the phronimon (64B5, apparently the brain which is the locus of the immortal soul or Iogistikon) 20 . and subsequently refers pleasurable sensations caused by sudden replenishmerits to the mortal soul (65A5). The effects of bad odors are said to extend from the head to the navel $\left.(67 \mathrm{~A})_{4}-5\right)$ and so would seem to affect the entire soul, both its mortal and immortal portion? 21. Similarly, hearing is described as a process extending not only to the brain and head $(67 B 3-4)$ but also to the liver (67B5). 22. And finally discussing the maintenance of mortal creatures, the Timaeus first introduces plants which are said to possess the epithymetikon and aisthesis (77B3-6) and then considers veins which not only water the body but also divide in the region of the head and so seem to serve the brain and logistikon in regard to sense perception (77D6-E6)23. ZZ. Whether or not we think that each of these passages presents a difficulty for the location of sensation within a bipartite version of tripartition, we can, $I$ think, agree that collectively these passages do indicate a problem. We can agree24. 24. that in the Timaeus Plato has not altered sufficiently his psychic framework to house the scientific (or biological) faculty of sensation. And we may suspect that when Aristotle critizes bipartition for its inability to handle sensation he is thinking of bipartition much as it appears in the Timaeus. $25 \cdot \mathrm{He}$ is thinking of certain members of the Academy who collapsed the spirited and appetitive faculties into one and so formed a bipartite version of tripartition. 
This suspicion seems to be to be confirmed when we reflect again on Aristotle's charge that bipartition splits up orexis (432b/4-6). Addressed to his own version of bipartition the charge is very odd. For Aristotle frequently refers to orexis as a mark of the alogical soul. 26. He never refers it to the logical soul. Further (and this is the important point), boulesis cannot be located in Aristotle's logical soul. 27. This is not just a matter of textual evidence, though the evidence of the Politics (1334b22-23) is important. It is also and primarily a matter of how Aristotle conceives of the dichotomy of bipartition. For Aristotle the dichotomy of bipartition is primarily a dichotomy between reasoned deliberation and emotional-response. Practical wisdom, which is the virtue of the logical soul, is a perfection of deliberation. Moral virtue, which is the virtue of the alogical soul, is a perfected disposition in regard to emotion (EN 1105\%19-1106a13). All emotion is located in the alogical soul. This is not true of tripartion and (we may add) the bipartite version of tripartition. For these Academic psychologies assign boulesis, aischyne, and possibly other emotions to the logistikon. 28. Each psychic part including the logistikon has its own peculiar drives and desires. 29. In contrast Aristotle's own moral psychology groups together all desires and emotions in the alogical soul. The logical soul is no longer the seat of desires and emotions like boulesis and aischyne. It is the seat of means-end deliberation. reasoned reflection concerning emotional response. Of course, reasoning can direct or alter desires and emotions, but it is distinct. In terms of Aristotle's own bipartite psychology, there can be no question of splitting up orexis and locating boulesis in the logical part. That question arises only when bipartition is conceived of as a simple variant of tripartition.

My conclusion, then, is that there are different kinds of bipartition and that a failure to note this difference has misled commentators into supposing that Aristotle's criticism of bipartition is in part a self-criticism. Aristotle is not criticizing his own moral psychology but rather an Academic version of bipartition that arose from tripartition by collpasing together the thymoeides and epithymetikon. Aristotle did not identify his own moral psychology with this variant on tripartition and would have objected to the (unqualified) suggestion that his own bipartite psychology developed out of tripartition.

1. For the importance of Medea's monologue see, for example, Mo Pohlenz, Freedom in Greek Iife and Thought (New York: Humanities Press, 1966),67; H. Görgemanns Beitrage zur Interpretation von Platons Nomoi=Zetemata 25 (München: Beck, 1960)159; J. J. Walsh, Aristotle's Conception of Moral Weakness (New York: Columbia, 1963) 16-22. See also my note 31 in "Aristotie: Fotion and Moral Virtue" Arethusa 2 (1969) 184 .

2. Jason would say, of course, that in some sense his actions, too, are guided by emotion. He would say that he is motivated by feelings of friendly affection, by a desire to aid and preserve Medea and her children $(595,620)$. But he would add that his emotional responses and subsequent plans can stand and have stood the test, of reasoned reflection. While Nedea's emotions motivate her to act in unreasonable ways, Jason's emotions do not. At least, Jason thinks he can defend and justify his own behavior.

3. It would be wrong to say that Medea's reasoned reflections alone effected a momentary change in her emotional response and plannod revenge. Certainly the sight of her children contributed to her momentary change. But so did her reflections and it is these reasoned reflections that are of especial interest. 
4. H. D. VoigtIänder ("Spatere Überarbeitungen im Grossen Medeamonolog", Philologus 101 (1957) 228), A. Iesky (in Euripide, Sept Exposés et Discussions (Geneve: Foundation Hardt, 1960) 83), and E. Schlesinger ("Zu Euripides' Nedea", Hermes 94 (1966) 29-30) point out correctly that boulernata is not restricted to a s.ngle, well defined (technical) usage. Certainly it is wrong to think that Euripides is operating with some clearly formulated psychology (like Plato's tripartite psychology, Schlesinger 29). But we can say that the opposition between thymos and bouleumata reflects an everyday distinction employed by ordinary men in describing human action and subsequently formulated in the dichotomy of bipartition. H. Strohm (Euripides $=$ Zetemata 15 (Milinchen: Beck, 1957) 103 n.I) seems to go too far when he says that bouleumata cannot be selected as a label to designate the opposite of thymos, because in 1079 bouleumata refers only to the preceding manthanein, while in 1048 bouleumata is used for the murder plans. Instead of ruling out bouleumata, this double usage may be thought to qualify bouleumata as a technical label for one half of the dichotomy of bipartition. Taking bouleumata inclusively so as to include both deliberations about means (murder plans) and reflections about emotiona: response (whether this kind of angry response is an over-response), we can see in the usage of bouleumata and its opposition to thymos a striking anticipation of Aristotle's logical soul and its opposition to the alogon.

Diller ("Thumos de kreisson ton emon bouleumaton" Hermes 94 (1966) 273-275) does not recognize in Euripides a wide usage of bouleumata signifying deliberation and reflection in general. He interprets 1079 so that anger mules or guides (kreisson, cf. Walsh (above, note I) 19 who seems to have anticipated Diller) Medea's plans (bouleumata having the same reference as in 1044 and 1048). This thesis is to me unacceptable. In the first place it seems more natural to construe bouleumaton (1079) closely with manthano (1078). By reasoned reflection Medea has learned that she is about to do evil (1078). But her reflections are powerless to affect her emotion so that she declares her angry emotion stronger than her reasoned reflections (1079). In the second place and more importantly, Diller's arguments seems to focus too closely on the single word bouleumata and on the monologue itself. We should, I think, take note of vedea's second meeting with Jason (866-893). For in the course of this meeting the emotion of Medea is said to be controlled by reasoned reflection and this reflection is twice $(893,913)$ referred to by words cognate with bouleumata. Perhaps similarities in vocabulary should not be pressed. Still it may be observed that this exchange between Medea and Jason agrees with the monologue in opposing thumos or a cognate form $(879,883$, 1056, 1079) to bouleuein or a cognate form (reflections: 882,893,913, 1079; plans or deliberations: 874,1044,1048) and in using the word logos in reference to reasoned reflection about emotional response $(872 ; 1052)$. Nore important, however, is an agreement in content. Both passages oppose emotional response to reasoned reflection. Both passages indicate one important respect in which emotion is commonly opposed to reason. Emotional responses are subject to rational criticism and in many cases can be altered by reasoned reflection. Indeed Medea's words to Jason are able to deceive just because Jason assumes that reasonable consideration will guide emotional response. Of course Jason is deceived in this matter. But as a working hypothesis his assumption is not foolish. Nuch of the time reflection is able to guide emotional response. But not always. For in Medea's monologue it becomes clear that reason can fail, that emotion may be stronger than reasoned reflection (1079). 
8.

5. A qualification is necessary. A virtuous man subjects his emotional responses to reasoned reflection when time permits. The virtuous man confronted with sudden danger does not have time to reflect. He must respond out of character and without reasoning (EN 1117a17-22). To illustrate further emotional response in sudden situations we may take a hint from Plutarch (Noralia 475A) and refer to Odysseus' meeting with the dog Argos. When Odyssess and Eumajos reach the palace, they come upon the ancient and all but dead Argos. The dog recognizes his former master and struggles in vain to move off the dung heap where he lies. Odysseus is moved by the pathetic sight of Argos and turns aside to wipe away a tear unnoticed by Eumaios $\left(291-305^{\prime}\right)$. As Plutarch comments, Odysseus fell into this situation quite suddenly and unexpectedly (475A). His behavior is not the result of reasoning (whether reflection about how one should respond to the situation or deliberation about how to prepare for the situation). Rather it is an expression of emotion quite in keeping with Odysseus character. He sheds a tear but also turns away and so escapes the notice of Eumaios. We can contrast this response with Odysseus' behavior a little earlier when reviled by the goatherd Melanthios. The words of Melanthios stir the heart of Odysseus (17.215-216). But after reflection Odysseus restrains himself (17.235-238). On this occasion Odysseus has time to reflect and to permit reason to control his emotional response.

6. We may add that the virtuous man heeds not only to his own reasoned reflections but also those of other men. Unlike the sullen man who hides anger within himself, so that no one can persuade him to give up his anger (EN 1126a23-24), the virtuous man pays attention to the reasoned arguments of others.

7. cf. Rhet. 1383a6-7 where Aristotle says that fear makes men deliberate. In other words emotional response is often the occasion for means-end deliberation.

8. I agree with D. J. Allen (The Philosophy of Aristotle (Iondon: Oxford, 1952) 182) that Aristotle never wanted to restrict practical wisdom to means-end deliberations. But I cannot follow Allen insofar as his argument: assumes an identity between the alogical soul. of bipartition and the sensitive and motive faculties of the scientific psychology. Comparisons with the scientific psychology will not help and may impede an adequate understanding of why the logical soul of bipartition is not restricted to means-end deliberation. To understand Aristotle's dichotomy we should keep in mind that emotional response (which includes cognition as well as sensation and drive) is related to reasoning in two different ways. As the Medea illustrates, an enraged person may engage in reasoning either to realize a goal or to reflect upon one's omotional state.

9. The Nedea can help us to understand Aristotle's assertion in the Politics (1260al3) that women possess the deliberative faculty (to bouleutikon), but lacking in authority (akuron). Aristotle does not mean that women are unable to think straight. His point is that their reasoning does not contrl their emotion. Just as Medea engaged in reflections (bouleumata 1079) concerning her response to Jason's betrayal but was not able to control her response, so for Aristotle women are able to reflect and in general deliberate (they possess to bouleutikon) but are unable to guide their emotions by reasoned reflection.

10. Elsewhere ("Aristotle's Rhetoric on Emotions", forthcoming in the Archiv för Geschiate der Philosophie) I have argued that Aristotle's moral psychology is significantiy different from tripartition, because tripartition did not draw a clear distinction between emotional responses and bodily drives. Aristotle's moral psychology is a dichotomy between reasoning and emotional response --those pathe that necessarily involve some assessment and so are amenable to reason. In contrast bodily drives are caused by physiological distrubance and are in gemeral not remedied by reasoned reflection. 
11. That Aristotle's criticism of bipartition applies in some way to his own bipartite psychology is either stated explicity or seems to be implied in the comments of the following scholars: Simplicius 289.7-19; Philoponus 574.1; F. Trendelenburg, Aristoteles, De Anima Libri Tres (Berlin: Weber, 1877)441; E. Wallace, Aristotle's Psycholegy (Cambridge: University Press, 1882)284; R. D. Hicks, Aristotle, De Anima (Cambridge: University Press, 1907)550; D. A. Rees, "Bipartition of the Soul in the Early Academy", Jourmal of Hellenic Studies 77 (1957)II8; R. Gauthier and J. Jolif, I Ethique a Nicomaqie (Iouvain: Fublication Universitaires, 1959) 2.93; W. Theiler, Aristoteles, Uber die Seele (Berlin: Akademie Verlag, 1959) 149-150; Sir David Ross, AristotIe, De Anima (Oxford: Clarendon, 196I) 312; A. Jannone and E. Barbotin Aristote, De L'Ame (Paris: Société Edition "Ies Belles Lettres", 1966) 109; D. W. Hamyln, Aristotle's De Anima (Oxford: Clarendon, 1968) 150. Cf.H.v. Arnim, "Das Ethische in Aristoteles Topik" SB Wien 205.4 (1927) 7,66; P. Moraux, Ie Dialogue "Sur la Justice"(Louvain: Publications Universitaires, 1957) 43-44; F. Dirimeier, Aristoteles, Nikomakische Ethik (Berlin: Akademie Verlag, 3rd ed.1964) 278; Arisoteles, Magna Noralia (Berlin: Akademie, Verlag, 1958) 164 .

G. Rodier (Aristote, Traite de L'Ame (Paris: Leroux, 1900) 529-530) suggests that the De Anima's criticism does not apply to Aristotle's bipartite psychology, because Aristotle does not commit himself to separate soul parts. Rodier is correct in ruling our Aristotle's own bipartite psychology as an object of criticism, but his reason does not get to the heart of the matter. The De Anima passage is concerned not only with whether or not there are spatially separate psychic parts (432a20), but also and primarily with how many parts or faculties are to be recognized (432a23). The advocates of bipartition are being criticized especially for having failed to distinguish adequately between the several psychic parts or faculties (432a24-26). And in this regard the criticisms developed in the De Anima do not seem to attack Aristotle's own brand of bipartition. Even if Aristotle's bipartite psychology did involve a commitment to separable psychic parts (and it did not, EN 1102a28-32), this particular bipartite psychology would not seem to be under attack. As we shall see, the attack of the De Anima is directed against an Academic-version of bipartition that differs in fundamental ways from Aristotle's own bipartite or moral psychology.

12. On the genuineness of this note see my article (above, note 1) 181-182, note 22. 13. See my article (above, note 1) 173-177 in which I have tried to explain why the divisions of the moral and scientific psychologies do not coincide neatly.

14. Cf. Noraux (above, note 11) 44,47 and Simplicius In De An. 289. 15-16.

15. On the necessary involvement of cognition in emotional response see my article referred to above, note 10. Here again it may be useful to refer to Euripides' Medea. At the outset of the play the nurse tells us that Medea perceives herself dishonored (26,cf.20) and so is filled with hate and grief. (16,24-35). Her emotional condition is not in doubt. It is Medea's deliberations that are unknown and of especial concern to the nurse (37). We should note that the nurse's remarks do not suggest a dichotomy that locates all cognition on the side of deliberation. Part of being angry is perceiving or thinking oneself outraged (26). This evaluation together with the desire for revenge may be distinguished both from the means-end deliberations that follow upon emotional response and also from the reasoned reflections that consider the emotional response - that is, the reasoning that asks whether the evaluation is correct and the desired goal appropirate, so 
10.

that the emstional response may be deemed reasonable and justifiable.

16. See Plutarch (Moralia 442B) who is correct insofar as he distinguishes the scientific faculties of nutrition and sensacion from the alogical soul of bipartition on the grounds that nutrition and sensation are bodily off-shoots without any share in logos.

17. We cannot construe De Anima $432 \mathrm{~b} 5$ to mean that boulesis is a logical oroxis only in that it responds to the injunctions of logos. (See Alexander 74.6-13). The De Anima passage is quite clear in its wording. Boulesis is said "to occur in the Iogistikon." As at Topics I26al3, boulesis is located in the logistikon. W. Newman (The Politics of Aristotle (Oxford: Clarendon, 1902) 3.456) (following Eaton) suggests that Aristotle's usage of boulesis is not uniform, for in the Politics boulesis is connected with the alogical and not with the logical soul as in the De Anima. Certainly the word boulesis is used in different ways. (See the remarks of H. G. Ingenkamp, Untersuchungen zu den Pseudoplatonischen Definitionen (Wiesbaden: Harrassowitz, 1967) 64-65.) For at least a partial understanding of the different usages of boulesis and especially for a fuller understanding of why the De Anima and Blitics differ in the locating boulesis, we should, I think, consider the possibility of two different kinds of bipartition: an Aristotelian version (Pol. 1334b6-28) and an Academic version that developed out of tripartion by bringing together the two lower faculties into a single alogon (cf. De An. 432b5-6 with Top.126a3-16 and see below).

18. At 439E5 Glaucon suggests that spirit is not some third psychic element but rather identical in nature to the appetitive element. At 571C3-572BI Socrates describes two different kinds of sleep by opposing the logistikon to the two lower elements. See Dirlmeier Nikomachische Ethik (above, note II) 278-279.

19. On tripartion in the Topics, see $\%$. Arnim (above, note 11). On 129al0-16 and bipartition, see Dirlmeier, Magna Noralia (above, note 11) 164. Iike De Anima 432a25-26, the Topics passage names the three psychic parts of tripartion. However, it groups together the spirited and appetitive parts in oppostion to the logistikon and so creates a bipartite version of tripartition. That this kind of bipartition is also under consideration in the De Anima seems clear from 432b5-6.

20. See the note of A. E. Taylor, A Commentary on Plato's Timaeus, (Oxford: Clarendon, 1928 ) 447.

21. For the navel as a boundary of the epithymetikon see 70El, 77B4. See also Taylor 476.

22. The liver is located in the region of the epithymetikon (7IA7-BI).

23. See Saylor 546-547.

24. With F. Solmsen, "Antecedents of Aristotle's Psychology and Scale of Beings", American Journal of Philology 76 (1955) 154-155.

25. It is not surprising that the De Anima's criticism of bipartition can be referred for elucidation to a literal interpretation of the Timaeus. We may compare how in Book I of the De Anima (406b26-407bll) Aristotle contrues (too) literally the myth of the Timaeus and so can fault Timaios' account of the world soul. (See Ross (above, note 1I) 189: "He (Ar.) may well be criticized as having taken the myth as if it were sober prose".) Certainly the objection to spatially separated parts (432a20) is directed most naturally against a version of bipartition (or tripartition) like that advanced in the Timaeus. For taken literally, the Timasus has a different bodily seat for each psychic part. Still, it would be a mistake 
to think that Aristotle's criticism is directed only (or perhaps even primarily) against the Timaeus. Most probabl.y Aristotle is criticizing a group (hoi de 432a26) within the Academy who followed the lead of Plato's l'imasus and endeavored to handle biological soul functions within a particular bipartite framework.

26. See for example EN 1102b30, 1139al7-b5;Pol. 1334b20. I say "a mark of the alogical soul" because I want to avoid the suggestion that the alogical soul is to be identified with the orektikon (together with the aisthetikon and phantastikon). I have argued already (see above with note 13) that the alogical soul is the capacity for emotional response and so includes not only moivive force (orexis), but also cognition. This is clearly implied at EN 1098a3-5. Still, for the purposes of reinting the suggestion that Aristotle's criticism of bipartition is a self-criticism, it does not matter whether the alogical soul is restricted to non-cognitive functions like orexis or includes certain cognitive functions. In either case all orexis belongs on the alogical side, so that Axistotle's charge of splitting up the faculty of locomotion cannot be leveled against his own brand of bipartition.

27. Cf. Gauthier and Jolif (above, notell) 2.193.

28. For boulesis and aischyne in the logistikon see Topics 126a8,13. Arnim (above, note 11) 74-76 suggests that philia and misos should be assigned to the logistikon and that philia is a kind of boulesis. Whether or not we follow Arnim in his interpretation of 126al2-13 (I do not think Arnim adequately explains 113b2), we must agree that philia is closely related to boulesis and that in his account of emotions Aristotle defines philein as a particular kind of boulesthai (Rhet. 1380b36-37).

29. The Republic states that each of the three psychic parts has its own epithumiai (580D). The logistikon is said not to care about wealth and reputation but to be directed wholiy toward knowledge (581A5-7). 